\title{
WOMEN'S SOLIDARITY INITIATIVES: \\ THE EXPERIENCE OF A COMMUNITY \\ DEVELOPMENT BANK
}

\section{EMPREENDIMENTOS SOLIDÁRIOS FEMININOS: A EXPERIÊNCIA DE UM BANCO COMUNITÁRIO DE DESENVOLVIMENTO}

Submission: $29 / 05 / 20$ Accept: 06/02/21

\author{
Kátia Regina Calixto Brasil ${ }^{1}$ \\ Fábio Freitas Schilling Marquesan ${ }^{2}$ \\ Rafael Fernandes de Mesquita \\ 1 Universidade Estadual do Piauí - UESPI, Teresina, Piauí, Brazil. \\ 2 Universidade de Fortaleza - Unifor, Fortaleza, Ceará, Brazil. \\ 3 Instituto Federal do Piauí-IFPI, Teresina, Piauí, Brazil.
}

\begin{abstract}
Purpose: The purpose of this research is to understand the relationship between the granting of microcredit in a community development bank and the performance of female solidarity enterprises.

Methodology: This research is descriptive with a qualitative approach and a theoretical-empirical nature. The data were submitted to the content analysis technique for organisation and interpretation of the findings.

Findings: From the results, it can be concluded that the granting of microcredit by the community bank can positively influence the performance of female solidarity enterprises, but it has some limiting factors, such as a low credit limit.
\end{abstract}

Originality: This study analyses the relationship between the microcredit concession processes and the development of female solidarity enterprises.

Keywords: Microfinance; Community development bank; Women's solidarity enterprises. 


\section{RESUMO}

Objetivos: O objetivo desta pesquisa é compreender a relação entre a concessão de microcrédito em banco comunitário de desenvolvimento e a atuação de empreendimentos solidários femininos.

Metodologia: A pesquisa descritiva tem abordagem qualitativa e natureza teórico-empírica. Os dados foram submetidos à técnica de análise de conteúdo para organização e interpretação dos achados.

Constatações: A partir dos resultados, pode-se concluir que a concessão do microcrédito por parte do banco comunitário pode influenciar positivamente a atuação dos empreendimentos solidários femininos, mas possui alguns fatores limitantes, dentre eles baixo limite de crédito disponibilizado.

Originalidade/valor: Análise da relação entre os processos de concessão de microcrédito e o desenvolvimento de empreendimentos femininos solidários.

Palavras-chave: Microfinanças. Banco comunitário de desenvolvimento. Empreendimentos solidários femininos

\section{INTRODUCTION}

The so-called "traditional banks" usually centralise and execute their activities based on formal and bureaucratic procedures, while the social Microfinance Institutions (MFI) combine formal and informal processes in their work (Esperanza \& Sánchez, 2018). MFI also invest in groups of Solidarity Enterprises (SE) organised for the development of their activities, in which the obligation to honour the payment of the loan is important for their social acceptance in the group and in society (Morduch, 1999; Parente \& Coelho, 2019).

In this context, Community Development Banks (CDB) act as a specific type of microcredit institution within the field of solidarity finance (Esperanza \& Sánchez, 2018). CDBs have made it possible for a portion of the low-income population to have access to microcredit by granting loans based on local social relations, trust, and social solidarity (Silva Júnior, 2007). This indicates the economic and social potential of such a system, acting as a possible alternative for the reduction of social inequality. Among the objectives proposed is local development based on the promotion of the so-called endogenous capacities (Reed, Marsden, Rivera, Ortega, \& Rogers, 2014). Endogenous capacity refers to the use of economic, social, and cultural potential that people have in a given location.

The collective microcredit, when granted by CDBs to a group of people, aims to assist with local difficulties, especially in terms of socio-economic development (Paredes, Paredes, Miño,\& Usca, 2019). The communal nature of this type of microcredit funds groups that work directly with the solidarity economy, expanding the ability to purchase, sale, and consume local products (Silva Júnior, 2007). Local development involves the establishment of community banks, social currency of movement, and cooperation between Solidarity Economy Enterprises (SEE), which requires efforts and perseverance of each community (Esperanza \& Sánchez, 2018).

Regarding the granting of microcredit, SEE formed and managed by women is a recurring phenomenon. According to Sanyal (2009), being a member of a microfinance group reinforces other forms of collective efforts organised by women, which boosts the existing cooperation between the members of these groups. Yunus $(2007,2010)$ argues that microcredit is an important tool for women in their support of local socio-economic development, and Aghion, Armenda'riz, and Morduch (2007) mention that women are more likely to pay the credit received than men. This argument converges with the motivation that many people have to search for a better quality of life for the family, a desire that is extremely common among low-income women; as a result, this group often seeks helps through SEE, seeking opportunities and improving local socio-economic conditions. 
Gender bias is also a factor: granting loans to women does not occur in a normative manner (i.e., in a formally established manner through its own regulation), but as a guide for the evaluation of the granting of microcredit. These guidelines are based on a methodology that originated in 1976 at Grameen Bank, Bangladesh, Asia and is now implemented worldwide (Yunus, 2007, 2010).

In light of the relationship between CDBs and the Female SEE, how are the processes of granting microcredit related to the development of female solidarity ventures? The focus of this study is the Banco Comunitário dos COCAIS - Piauí because the women who manage SEE had a decisive role when it was first established. The SEE groups, the majority of which take out microcredit with the bank, were tasked with acquiring raw materials and expanding the production and marketing of their products that were provided by the productive credit line. In this sense, the objective of this study is to understand the relationship between the microcredit concession processes and the development of female solidarity ventures.

\section{MICROFINANCE, MICROCREDIT, AND COMMUNITY DEVELOPMENT BANKS}

Microfinance was created to provide opportunities and improve the living conditions of a population that does not have access to the traditional financial credit system (Parente \& Coelho, 2019). Historically, the need for assistance and policies aimed at serving low-income people initiated the establishment of microfinance institutions, which are effectively geared towards combating poverty through the granting of microcredit (Paredes et al., 2019). Positive initiatives for the creation of these institutions in countries such as Bangladesh, Indonesia, and Bolivia in the 1970swere fundamental for the expansion of access to financial credit; because they are committed to serving a disadvantaged portion of the population, they are fundamental for expanding access to financial credit worldwide (Morduch, 1999).

The provision of financial services (loans, savings, insurance, etc.) suitable for the area of microfinance is aimed at people who normally do not have access to the traditional financial system. For this provision of services to reach the target audience, it is necessary that these institutions qualify as one or more of the following: Non-Governmental Organizations (NGOs), Civil Society Organizations of Public Interest (CSOPI), Credit Cooperatives, Credit Societies for the Small and Microentrepreneurs (CSSM), Public Funds, or Public and Private Commercial Banks (Parente, 2002).

Poverty reduction is an explicit or implicit benefit of most microfinance programs. Historically, poverty was seen as a problem for the poor who earned little income. Consequently, they consumed very little to achieve a socially acceptable standard of living and had few resources to protect themselves against unforeseen problems. This concept does not consider the most complex social issues involved in this scenario, however (Bruton, Khavul, \& Chavez, 2011).

Brazilian activities focused on microfinance are mostly understood as financial actions directed at small entrepreneurs with specific and formal regulation. The focus of such activities is on serving those who do not have access to traditional credit or other basic needs and who use strategies in the services provided to achieve results with its target audience (Marconatto, 2013).

The primary challenge regarding microfinance in Brazil is the immense popularity of its services; because approximately 40 to 80 percent of populations in developing countries, whose economies are relatively strong but do not have access to the formal financial system, utilise such services, microfinance at the global level needs to be drastically expanded (World Bank, 2007). Yunus and Banco Grameen's pioneering research on the worldwide repercussions of microcredit and the establishment of Grameen Bank in Bangladesh in the late 1970s (Yunus, 2007) helped to establish a consensus regarding the importance of microfinance, proving that poor people can honour their loans (Cull, Demirgüç, \& Morduch, 2009). 
There is an unsolved question about why traditional Financial Institutions are not successful in providing credit to the poor. Financial Institutions have pointed out, namely, that the poor are mostly illiterate, have no formal guarantees, have no credit history with banks, and operate in the informal economy, and the vast majority create unregistered and unpaid companies (Portes \& Haller, 2005; Webb, Tihanyi, Ireland, \& Sirmon, 2009).

In Brazil, problems with informal microcredit aimed at the urban public first arose around 1973 between the Northeastern Union of Assistance to Small Organizations in the cities of Recife and Salvador. International organisations such as the Inter-American Development Bank (IDB) and the German Technical Cooperation Society have also acted as partners in some initiatives. The first formal microcredit organisation established in Brazil was the Ana Terra Support Center for Small Enterprises (CEAPE) in Porto Alegre-RS (Barone, Lima, Dantas, \& Rezenda, 2002).

Microcredit is understood within the context of microfinance and is treated as a service provider dedicated exclusively to small and entrepreneurial individuals and small businesses (Esperanza \& Sánchez, 2018). These individuals have real needs for loans, but they have almost no financial resources to open, expand, and/or obtain working capital for a small business (Neri, 2008).

Often the activities that are developed, such as baking bread, crafts, sewing, making homemade sweets, and establishing street vendors, are fairly simple, but have made immense differences in the communities. Other primary activities of the microfinance sector directly relate to public policy programs aimed at combating poverty and generating employment and income (Greatti \& Sela, 2017).

In the 1990s, the concept of a social bank was adequate, following existing models in the market that participated in the granting of microcredit and in line with solidarity practices (use of formal guarantees, granting a loan without finding out that there would be an income generation local or construction of joint supply and demand, etc.) through which commercial banks created special portfolios suitable for the concession of microcredits to the informal sector and to micro and small companies (Silva Júnior, 2007).

The Community Development Bank (CDB) is a provider of financial solidarity services that works in a network of an associative and community nature and is aimed at the reorganisation of local economies through the generation of work, income, and the Solidarity Economy. CDBs work with the circulating social currency that is only accepted in the local, territorial space where it is inserted and used to pay for a certain service or product. It is widely used in microcredit, as it enables small economic activities as well as local socio-economic development (Freire, 2008; Lietaer \& Primavera, 2013). Soares (2011) supports this idea, citing that it is a parallel currency created and administered by its own users in a given community. The social currency is intended to transform reality and democratise access to wealth; therefore, its circulation in the local market is necessary (Greatti \& Sela, 2017).

The circulation of a local social currency among the users of the community in which it is inserted generates a social return while providing these people with the ability to acquire economic and symbolic goods that were hitherto unattainable through the traditional currency. Through the granting of credits, CDBs make it possible for people that were previously relegated to a secondary level to socialise (França Filho \& Laville, 2004).

A celebrated innovation in the microfinance area is the creation of the group loan contract (Esperanza \& Sánchez, 2018). These contracts reach a greater variety of groups in terms of developed economic activities and help to establish social relations between their members to help in the asymmetry of information, thus reducing the number of possible problems between the financial institution and the borrower (Morduch, 1999; Portes \& Haller, 2005).

Group loan contracts are alternative solutions for reducing the transactional risks that an MFI may cause when the instalments of a loan are not paid. The co-responsibility between the pairs of these groups means that, in most cases, the payment terms of the loans are fulfilled, making the 
transactional risk lower (Ghatak \& Guinnane, 1999; Marconatto, 2013). In the event that a solidarity group does not pay the loan, there is a collective punishment since the responsibility is a shared one, meaning that all group members are prevented from taking credit in the financial institution in the future, even on an individual basis (Esperanza \& Sánchez, 2018). This pending period lasts until the loan is paid off (Ghatak \& Guinnane, 1999).

Karlan (2007) argues that a supportive environment helps the groups properly monitor the credit received, and that people pay their loans when they feel that they have established bonds of friendship in the group. According to Ghatak and Guinnane (1999), one of the main obstacles to solidarity responsibility in group loans arises when the social ties between the group's participants are weak, which makes it difficult to support the feelings of solidarity in the group. Studies developed in several countries report that social cohesion is a greater factor for repaying the loan than the trust that people have for the society in general (Cassar, Crowley, \& Wydick, 2007).

The World Bank (2002) indicates that reimbursement is higher among female borrowers, mainly due to more conservative investments and a lower moral hazard risk. Moreover, Johnson (2004) points out that women's business in activities often implies a quick return, which is more adaptable to the payment instalments that are required by most IMFSon a regular basis.

According to Kevane and Wydick (2001), the female borrowing groups have better records of loan payments on a larger scale than the male borrowing groups. While this does not mean that there is a direct relationship between gender and payment record, since what may be there is an adaptation of the groups regarding the loan and the methodology used by the MFI in the local context as a factor of strong appeal (Bhatt \& Tang, 2002). According to Brehanu and Fufa (2008), in addition to these local adaptations, local economic opportunities and the livelihoods of the clients are additional factors to be considered.

Also, according to the World Bank (2002), microcredit programs and informal financial systems facilitate women's access due to the absence of requests for formal guarantees for the granting of credits. However, several debates still exist around the world in regard to these programs and female participation (Paredes et al., 2019) since female emancipation in some parts of the world did not take place until the 1980s or later. Rahman (1999) cites "transcript public" as a justification since these loans granted to women allowed them to make financial gain and have a larger role in the family's social welfare as opposed to men. The gender norms forced women to take the most basic needs for the family into their homes; this situation differed from men, who typically left their homes and/or deviated from the family's needs when acquiring credit, often refusing to collaborate on decisions regarding the purchase of basic food items for the family.

A woman still often feels embarrassed where she presents any signs to the group of having difficulties in paying off her portion of the loan; she does not want to be singled out as a person who does not honour her commitments. After signing the contract that grants them the credit, women also feel obligated to inform their children about a possible seizure of assets belonging to their home in the event of a default with the MFI.

One of many purposes of women's participation in associative groups is the creation of opportunities for work and income using the principles of self-management and cooperation (Parente $\&$ Coelho, 2019). This has shown a very sharp growth and can be a way to face the socio-economic inequality that is presented in the market. These collective organisations are considered to be factual alternatives to the capitalist system, allowing citizens, residents of a particular place, consumers, and workers to be inserted into the labour market, even if only informally (Greatti \& Sela, 2017).

Ardener and Burman (1995) discuss the various reasons that women form solidarity groups, namely that social sanctions have a greater bearing on women because they can bring shame in the society in which they live, and that solidarity is more present among the participants because they 
are all equally responsible for the loan. According to Ardener and Burman (1995, p.13), an important factor for women's motivation to work in groups relates to the fact that the most experienced women teach the youngest, both in terms of the development of activities and expressing themselves in public. This social hierarchy among the participants makes women stand out in relation to their husbands, showing that they are capable of running businesses.

The division of labour is carried out on an equal basis so that responsibilities are shared among all participants equally, immensely facilitating the distribution of work and income. Women also prefer to work with women without the participation of men, forming homogeneous groups; the line of command and responsibility is thus respected by all members, a situation that would be difficult in heterogeneous groups (Ardener \& Burman, 1995).

\section{METHODOLOGICAL PROCEDURES}

The research uses a qualitative approachto analyse and interpret the complexity and subjectivity of the respondents' answers (Mesquita \& Matos, 2014). For data collection, a pre-test was carried out with the bank's managers and with two SEE representatives governed by women. After this data were collected, the researchers returned to the city of São João do Arraial, where Banco dos Cocais is located, and carried out interviews with the current manager of the bank, as well as with seven representatives of the groups administered by women.

The research mainly focused on collecting information from women representatives of the SEE groups that started work with the community bank of local development when it was first established in December 2007 and remained active until December 2016. Representatives from the nine different groups of activities were chosen according to their ability to respond to the interview script, which elaborated upon elements identified in the theoretical framework. The interviews were carried out with the representatives of the women's groups in one of the following locations: bakery, craft store, community garden, horticultural store, perfumery and cosmetic department, variety store, snack stand, studio, or clothing store. The two coordinators of the COCAIS community bank (current and previous) and a specialist in the subject were also present for each interview. In addition, some documents were also analysed that verified the percentage of credit taken by female ES groups since the bank's implementation in 2007 until 2016 in the municipality of São João do Arraial.

Table 1. List of Respondents

\begin{tabular}{cc}
\hline Interviewee & Function \\
\hline A & Thematic specialist \\
B & Bank deployment coordinator \\
C & Coordinator (current) \\
D & Group representative (crafts) \\
E & Group representative (bakery) \\
F & Group Representative (Ateliê) \\
G & Group Representative (variety store) \\
H & Group representative (community garden) \\
I & Group Representative (perfumery and cosmetics) \\
J & Group Representative (rural clothing store) \\
K & Group Representative (urban clothing store) \\
L & Group Representative (barraca de lanches)
\end{tabular}


The answers to the interviews and the documents made available by Banco dos COCAIS were transcribed in order to analyse the importance of the target audience in strengthening the solidarity enterprise for the MFI aimed at the community. The content analysis (Mendes \& Miskulin, 2017) of the research was divided into three phases: the pre-analysis, where the material is read superficially and the most used concepts in the answers and in the choice of documents are extracted; in the case of this research, the interview and the financial documents from the community bank were deemed essential for achieving satisfactory results.

\section{DATA ANALYSIS AND DISCUSSION}

The locus of this study is the COCAIS-PI Community Development Bank, located in the municipality of São João do Arraial, $203 \mathrm{~km}$ away from the capital of the state of Piauí. According to data from the Brazilian Institute of Geography and Statistics (IBGE, 2015), the state has an estimated population of 7,755 inhabitants, of which 3,695 are men and 3,641 are women (IBGE, 2015). According to the Palmas Institute, Piauí has implemented three CDBs through the Network of Community Banks in Brazil: the opal bank in Pedro II, the Marruás Bank in Porto, and the COCAIS bank in the municipality of São João do Arraial (R.E.D.E, 2006).

Banco dos COCAIS's activities began with the offer of two lines of microcredit: solidarity microcredit, aimed at individuals who were experiencing difficulties in their daily lives, and productive microcredit, granted to the collective solidarity economy group. New loans were granted as group instalment payments were paid off. This strategy helped the groups pay earlier so other initiatives waiting for credit were less likely to be affected.

The Banco dos COCAIS microcredit concession follows a specific methodological orientation passed on by the Palmas Institute, which is responsible for replicating all community banks located in Brazil. This methodology allows for a local adaptability different from commercial banks, providing an opportunity for people who do not have enough income to access traditional credit to instead receive microcredit.

When Banco dos COCAIS was first implanted in 2007, female ES groups were trained through the Social Assistance Reference Center (CRAS), an agency linked to the Municipal Social Assistance Secretariat in the municipality of São João do Arraial-PI. The agreement established between CRAS and Banco dos COCAIS stated that women were trained to start their solidarity economic activities through production groups. After this training, Banco dos COCAIS began to release productive microcredit to two groups that were pioneers in receiving microcredit: the bakery women's group and the handicraft women's group. Productive credit had a maximum ceiling of $\mathrm{R} \$ 800.00$ per group, which meant that these groups had an agreement with the bank because the credit value was very low and in constant need of more credit.

According to the data collected in this research, the COCAIS Community Development Bank works with a portion of the population in the municipality of São João do Arraial (PI) that is considered to be poor and does nothave access to microcredit concession. As Morduch (1999) explains, the bank's hope is that, by providing financial services to low-income families, poverty can be alleviated via economic and social structures. These institutions, united under the banner of microfinance, share a commitment to serve customers who have been excluded from the formal banking sector.

The granting of credit at the BOC dos COCAIS consists of a few stages, beginning with a registration form that is filled out by the representative of the applicant group. After they complete this registration form, the credit agent goes to the address provided to verify the information and possible notes that may be necessary. The COCAIS community bank has a Credit Assessment Council (CAC) that meets monthly to evaluate loan requests and analyse whether or not to release the requested amount, taking into account the type of business of the group, the requested amount, whether the group con- 
sists of women, what impressions the group made during the visit of the credit agents, and the bank's financial availability. The CAC is composed of three to five people from the bank's management board, including the general coordinator, credit agent, financial coordinator, and project coordinator.

According to França Filho, Rigo, and Silva Júnior (2013), credit applications and collections are judged based on a social control mechanism between the components of CAC that is formed by people from the community; this differs from the formalist approach of the traditional financial system that requires an excessive number of forms and documents and is governed by specific legislation. In addition, the relationship between the women's group and the neighborhood and the sensitivity of credit agents are also considered because they are aware of the reality of credit borrowers and directly assist CAC in the information on the specifics of each case. After the credit is approved, the representative of the female solidarity group is summoned to sign the contract and the amount is released to begin the proposed activities.

Another equally important phase in the release of credit concerns the methodology used by the community bank for solidarity groups that are requesting credit for the first time. The COCAIS CDB manager reports that, after the registration is validated, he schedules an awareness meeting with the group to discuss the importance of credit while also addressing basic notions about what is a solidarity economy, the importance of credit investment, the possible consequences of non-payment of the loan, and how not to confuse productive credit with the payment of personal bills, among other points. According to Ghatak and Guinnane (1999), it is important that the bank uses specific procedures and follows its own methodology when credit is released. The authors also mention that the Bank Grammen in Bangladesh adopted some procedures for granting small loans to groups of women; for example, they required participants in the group to reside in the same location, receive training from bank employees after the group was formed, attend weekly meetings, and make repayments weekly and in small amounts to the bank.

For female SEE, the credit granting process is clearly defined and consists of steps outlined through a specific methodology that is related to the CDBs implemented in the national territory. This methodology and the processes employed make the criteria that are used by the bank to grant the requested credit, in addition to feedback to customers when applying for the loan, clear and defined. The steps allow the participants to follow their claim more closely, which greatly facilitates their understanding of the process.

The management of the processes and the necessary methodology for the operation of Banco dos COCAIS was passed on by a team from the Palmas Institute (CE), an institution that is responsible for ensuring that the same methodology is implemented across all community banks in the national territory. According to Morduch (1999), microfinance was a promise founded on innovation, with new management structures, new contracts, and new attitudes in the main programs emerging through trial and error. Once the mechanisms worked reasonably, standardisation and replication became a priority.

With the use of a specific methodology for the granting of small credit, it is important that the population believes in the proposal of the community bank and begins to understand the need to circulate the local social currency in commerce to streamline transactions commercial. Interviewee $B$ articulates this concept:

To give you an idea, at the beginning, for some merchants, we used the discourse that we would open credit for families and that these families would have to spend, and the merchants started to see that they either accepted or were going to lose customers. So they ended up accepting all the commercial institutions and put the sign 'we accept COCAIS.'- Interviewee B 
With the establishment of Banco dos COCAIS in the city of São João do Arraial (PI) in 2007, local commerce improved the socio-economic activity of the area; now, people did not to travel 30 $\mathrm{km}$ to the neighbouring city in order to receive their wages and make purchases in stores. The local social currency, the Cocal, is now accepted by all traders, and its circulation stimulates the local economy. According to Freire (2008), the purpose of a social currency is to be used as a means of payment for purchases made only in the territory where the MFI is located, which further generates income through activities and stimulates local socio-economic development. Moreover, França Filho et al. (2013) point out that close and trusting relationships between people and the circulating social currency very objectively and effectively support the socio-economic relationships built through the use and exchange of social currency.

Another benefit of social currency is its promotion of local cultural symbols that are printed on circulating paper money, which motivates people to further value their own culture and beliefs. The Cocal has a symbology that is presented through drawings made on the banknotes; because it is a babassual region, the notes represent the local economy with figures of babassu palm, and women breaking or treading the coconut, which symbolises the solidarity economy of babassu coconut breakers. Rigo (2014) states that the use of symbols on the social currency in the local territory has a educational purpose and can spark feelings of citizen appreciation; the symbology tells a story and helps individuals establish identity relationships with the place.

One of the strategies used by the bank's management committee to disclose, give access to, and boost the relationship with the local population was through the establishment of partnerships. These partnerships were necessary because they helped increase circulation of the social currency of COCAIS in local commerce, making its use more economically dynamic in commercial transactions between actors.

Banco dos COCAIS has an agreement with the City Hall to pay up to $25 \%$ of the civil servants' salaries in the local current social currency, the Cocal. The Bank also has another agreement with the city government to make payments for outsourced services, such as garbage collection, services rendered by third parties, bonds, water, energy, and day labour. The bank is a banking correspondent for Banco do Brasil (BB) and Caixa Econômica Federal (CEF) that pays the family allowance and receives water and electricity bills as well as payment slips from residents. It has a partnership with the Federal University of Bahia (UFBA) to provide consultancy services in the municipalities that wish to implement CDBs. These partnerships give the bank a financial increase at the end of the month due to the passthrough percentages of each service provided. For Morduch (1999), most programs of Microfinance Institutions continue to be subsidised directly through official subsidies and indirectly through signed terms because the cost of maintaining the structure of an MFI is very expensive.

The transactional cost becomes higher and riskier when there is no request for any type of guarantee to grant credit. The basis of the business relationship is trust, which in some ways is risky for less than the financial value borrowed. Regarding the request for formal or informal guarantees for the granting of microcredit, the COCAIS bank does not recommend transferring any type of guarantee; it only requests the signature of the contractor in the formalised document. According to Morduch (1999), the guarantee is not always requested from borrowers who have limited resources in microcredit programs because this does not necessarily mean that they will struggle to pay.

Besides not requiring any type of guarantee, the COCAIS bank has a credit line aimed at encouraging the economic development of the groups. This can be considered a positive factor because it helps attract certain groups; having an interest rate policy below the traditional market can, in a way, make the payment of the loan viable without compromising the income generated by the business at the end of the month. 
The credit lines worked by the COCAIS bank are: a) solidarity credit, aimed at people who have difficulties in their daily lives and do not have financial resources (purchase of gas and medicines), with a maximum availability of C $\$ 50.00$ (fifty COCAIS) and a payment term of 30 days; and b) productive credit, aimed at groups of female ES that aim to encourage the purchase of raw materials for making products, with a maximum loan amount of $\mathrm{R} \$ 1,000$ and interest of $1.5 \%$ per loan. Group loans can provide benefits by inducing borrowers not to take risks that undermine the bank's profitability, as this can be considered a moral risk. As stated by França Filho et al. (2013), the purpose of making credit lines available is to make consumption within the community possible through the local circulating social currency, satisfying the most urgent needs of credit applicants when necessary. The fact that the credit lines generate interest below the traditional financial market (from $1 \%$ to $2.5 \%$ per year) allows the community to generate income as well as job opportunities (Rigo, 2014).

The nature of the local economy provides groups formed by women with some advantages when receiving credit (Parente \& Coelho, 2019). Since they have a greater focus on the activities they wish to invest in and have established friendship bonds with one another, banks often prioritise granting loans to them because they have greater mobilisation power than men. This stance is discussed in more detail in the following quotations from interviewees:

We find it advantageous to lend money to women's groups because they are good payers. As people know each other in a small town like ours, everyone watches and controls so that people pay the loans because they know that only with the payment on time will other people be able to borrow from the bank. - Interviewee $B$

We deal with needy people; this is justified for us because we know everyone, the house where they live, what they do. The city is small and has 8,000 inhabitants, so everyone knows everyone's life. We have confidence in people and they pay.- Interviewee $C$

The credit agent visits the place, goes to the borrower's house, talks with the neighbours about the person, and with that we establish a trusting partnership with the neighborhood. They feel responsible for the loan and warn us when they feel there may be a problem. Interviewee B

Banco dos COCAIS are more willing to grant collective loans for higher education groups because group participants feel co-responsible for the money requested and normally take responsibility for the members' instalments when they cannot pay. The trust placed in the groups is the basis for the loan, as the bank believes that everyone deserves an opportunity. The credit borrower's neighbourhood plays an important role in the process, passing on information to bank agents when asked to collaborate with the project's monitoring. According to Morduch (1999), the programs point to innovations in "loan group" contracts and new attitudes about subsidies as keys to their success. In addition, neighbours have incentives to monitor each other and to exclude risk-takers from participation, refunds, and promotion, even in the absence of guarantee requirements.

Also, according to Morduch (1999), the ability of neighbours to enforce contracts and monitor each other, even when the bank can do so under a group loan agreement, offers a way to lower equilibrium interest rates and increase the expected utility as well as the expected reimbursement rates. The stronger the vigilance practiced by neighbours, the greater chance the group loan has for carrying out "safe" projects rather than riskier and less profitable ones. As Ghatak and Guinnane (1999) argue, group loan contracts effectively make the borrower co-signatory neighbours for loans, even mitigating the problems created by information asymmetries between the lender and the borrower. Another aspect that is considered positive for groups administered by women concerns the default rate, which is minimal among clients. 
The issue of defaults on loans is considered practically non-existent by COCAIS Development Bank because, even if some group or individual does not pay the loan, they can go to the bank to justify their situation and set a new payment date without the interest increasing. According to Morduch (1999), financial institutions have loan repayment rates in all cases above $95 \%$. The programs have also been shown to better assist poor individuals and women in particular who are difficult to reach through traditional financial approaches.

One of the ways the bank found to minimize delays in the instalment payments of the loans is to leave it to the borrower to decide how to instal the loan in instalments. In a way, this strategy is advantageous and important in the negotiation process, as it makes clear that clients can decide on their own financial conditions. However, some limitations were found in the research in regard to the granting of credit, one of which is the low financial limit established by the bank to grant credit to groups; this is a constant complaint from the representatives of the ES groups, and the bank's coordinator also admitted that is was an obstacle.

Interviewee C, the bank's coordinator today, believes that this credit limit is one of the reasons why many groups do not remain active with the bank. However, he ponders that

(T)he purpose of our credit is not that they [the groups[ become dependent on it but rather independent; that they create autonomy to run their business...our credit is for those people who have small businesses and that others banks don't see it, they don't see a business opportunity like us.

Marconatto et al. (2016) argue that community banks should have regularisation in order to be able to participate in programs that support microfinance with the granting of federal subsidies to IMFS; their collaboration with public policies could improve access for people excluded from the traditional financial system. This could also make it possible to increase the financial value of loans, as is already the case with large commercial banks in the country. Another limitation encountered in the research concerns new loans: for new loans to be granted, the previous loan must be paid off. The bank does not allow other people to participate in the group to sign new contracts for the same purpose, which differs from the practice of traditional financial institutions that work with consignment margins. If there is a need for a new financial contribution, the request is analysed by the bank's management committee.

Initial loans are prorated between groups in small amounts so that the bank can reach the largest number of groups who can benefit from the credit available. In the course of repaying loans, the bank makes larger amounts available to groups considered to be good payers. Good payers are understood to be those who do not delay instalments and, in many situations, anticipate payment in instalments when paying off the loan. Programs of microfinance institutions usually begin by lending only small amounts and then increasing the size of the loan through a satisfactory repayment. Bruton et al. (2011) mentions that the initial loan is made available in small quantities, but if all members of a group are meeting their monthly financial obligations, the borrower is eligible for subsequent larger loans once a loan is repaid.

\section{CONCLUSION}

In this paper, we attempted to describe a community development bank's process of granting microcredit and the performance of female ES. The process has its own methodology that is passed on by the Palmas Institute and has been adopted by all community banks located in the national territory. The following positive aspects of the process were identified: the management of the processes and 
methodology for granting credit; the acceptance of the social currency in all local commerce; the clients' belief that the bank belongs to the local people; the existence of bank partnerships (covenants); the absence of formal and informal guarantees for granting credit; a personal credit line for the granting of credit (productive); prioritising the granting of credit to collective groups of women; the role of the neighbourhood as co-participants in the credit release process; feelings of trust between the parties involved in granting credit; low default/delay in accountability; and the value of the instalments that are defined by the borrower. The limiting factors of the process are the credit limit granted by the bank and the obligation to settle the loan in order to grant a new loan.

Despite the limitations of the credit value and the fact that the bank does not work with a consignment margin to allow group members to take out more loans, access to credit allows people to have their own business and to participate in activities for which they have the knowledge to further develop. Given the choice of the Cocais bank as a reference case for the analysis developed in this study, a limitation of the research is the unique geographical situation; however, this can be overcome with new research works in other regions of the country. This geographical expansion can contribute to comparative studies that take this paper as a basis for comparison. The gender of the research participants was also an intentional choice and could be a limiting factor on the results and interpretations.

\section{REFERENCES}

Aghion, B. A., Armendáriz, B., \& Morduch, J. (2007). The economics of microfinance. MIT Press.

Ardener, S., \& Burman, S. (1995). Money-go-rounds: The importance of rotating savings and credit associations for women. Berg Publisher Ltd.

Barone, F. M., Lima, P. F., Dantas, V., \& Rezende, V. (2002). Introdução ao microcrédito. Brasília: Conselho da Comunidade Solidária, 65.

Bhatt, N., \& Tang, S. Y. (2002). Determinants of repayment in microcredit: Evidence from programs in the United States. International Journal of Urban and Regional Research, 26(2), 360-376.

Brehanu, A., \& Fufa, B. (2008). Repayment rate of loans from semi-formal financial institutions among smallscale farmers in Ethiopia: Two-limit Tobit analysis. The Journal of Socio-Economics, 37(6), 2221-2230.

Bruton, G. D., Khavul, S., \& Chavez, H. (2011). Microlending in emerging economies: Building a new line of inquiry from the ground up. Journal of International Business Studies, 42(5), 718-739.

Cassar, A., Crowley, L., \& Wydick, B. (2007). The effect of social capital on group loan repayment: evidence from field experiments. The Economic Journal, 117(517), F85-F106.

Cull, R., Demirgüç-Kunt, A., \& Morduch, J. (2009). Microfinance meets the market. Journal of Economic Perspectives, 23(1), 167-192.

Esperanza, L. M. Z., \& Sánchez, R. A. Z.(2018). Relación entre el microcrédito y género en el cantón Ambato. Visionario Digital, 2(4), 39-49.

França Filho, G. C., \& Laville, J. L. (2004). Economia solidária: Uma abordagem internacional.UFRGS Editora.

França Filho, G. C., Rigo, A. S., \& Silva Júnior, J. T. (2013). Microcredit policies in Brazil: An analysis of community development banks. In I. Hillenkamp, F. Lapeyre, \& A. Lemaître (Eds.), Securing livelihoods: Informal economy practices and institutions(pp. 115). 
Freire, M. (2008). Moedas Sociais: $O$ que são, como funcionam e porque podem ser consideradas instrumentos de desenvolvimento local. In: Seminário banco central sobre microfinanças (pp. 7). Anais... Belo Horizonte, 2008. Retrieved from: http://bit.ly/1MJtKts

Ghatak, M., \& Guinnane, T. W. (1999). The economics of lending with joint liability: Theory and practice. Journal of Development Economics, 60(1), 195-228.

Greatti, L., \& Sela, V. M. (2017). Instituições de microfinanças: Atores na implementação da inclusão financeira no Brasil. Revista Metropolitana de Governança Corporativa, 2(2), 52-74.

Instituto Brasileiro de Geografia e Estatística[IBGE].(2015). Retrieved from: <http://cidades.ibge.gov.br/ xtras/perfil.php?lang=\&codmun=220997\&search=| | infogr\%E1ficos:-informa\%E7\%F5es-completas

Johnson, S. (2004). Gender norms in financial markets: Evidence from Kenya. World Development, 32(8), 1355-1374.

Karlan, D. (2007). Social connections and group banking. The Economic Journal, 117(517), 52-84.

Kevane, M., \& Wydick, B. (2001). Microenterprise lending to female entrepreneurs: Sacrificing economic growth for poverty alleviation? World Development, 29(7), 1225-1236.

Lietaer, B., Primavera, H. (2013). Moedas complementares, bancos comunitários e o futuro que podemos construir. In: Instituto Palmas \& NESOL-USP (Eds.), Banco Palmas, 15, (pp. 61-74).

Marconatto, D. A. B. (2013). A influência das três forças sociais sobre as atividades de avaliação, monitoramento e enforcement executadas por instituições de microfinança socialmente orientadas de empréstimos individuais em um país desenvolvido e em um país em desenvolvimento. Doutorado em Administração, Escola de Administração, Programa de Pós Graduação em Administração. UFRGS: Porto Alegre.

Marconatto, D., Cruz, L. B., \& Pedrozo, E. A. (2016). Going beyond microfinance fuzziness. Journal of Cleaner Production, 115, 5-22.

Mendes, R. M., \& Miskulin, R. G. S. (2017). A análise de conteúdo como uma metodologia. Cadernos de Pesquisa, 47(165), 1044-1066.

Mesquita, R. F., \& Matos, F. R. N. (2014). A abordagem qualitativa nas ciências administrativas: Aspectos históricos, tipologias e perspectivas futuras. Revista Brasileira de Administração Científica, 5(1), 7-22.

Morduch, J. (1999). The microfinance promise. Journal of economic literature, 37(4), 1569-1614.

Neri, M. C. (2008). Microcrédito, o mistério nordestino e o Grameen brasileiro: Perfil e performance dos clientes do Crediamigo. FGV Editora.

Paredes, M. C. M., Paredes, V. R. M., Miño, S. P. V., \& Usca, M. D. L. M. (2019). El microcrédito como facilitador de empoderamiento. Experiencias de mujeres del sector rural de Chimborazo. $L a$ Ciencia al Servicio de la Salud, 10(Special Edition), 353-361.

Parente, S. (2002). Microfinanças: Saiba o que é um banco do povo. AED.

Parente, T. G., \& Coelho, E. C. (2019). Microcrédito e (des) empoderamento das mulheres beneficiárias no banco do povo em palmas/to. Revista Observatório, 5(2), 480-512. 
Portes, A., \&Haller, W. (2005). The informal economy. In N. J. Smelser \& R. Swedberg (Eds.), Handbook of economic sociology. New York, NY: Russell Sage Foundation.

Rahman, A. (1999). Micro-credit initiatives for equitable and sustainable development: Who pays?World Development, 27(1), 67-82.

Bancos Comunitários, R. E. D. E. (2006). Banco comunitário: Serviços solidários em rede. Fortaleza: Instituto Banco Palmas.

Reed, L. R., Marsden, J., Rivera, C., Ortega, A., \& Rogers, S. (2014). Resilience: The state of the Microcredit Summit Campaign report. Washington, DC: Microcredit Summit Campaign.

Rigo, A. S. (2014). Moedas sociais e bancos comunitários no brasil: Aplicações e implicações, teóricas e práticas (Unpublished doctoral dissertation). Federal University of Bahia, Salvador.

Sanyal, P. (2009). From credit to collective action: The role of microfinance in promoting women's social capital and normative influence. American Sociological Review, 74(4), 529-550.

Silva Júnior, J. T. (2007). Bancos comunitários e desenvolvimento territorial: Analisando as singularidades destas experiências de microfinanças solidárias. Cadernos Gestão Social, 1, 1-18.

Soares, C. L. B. (2011). A Moeda Social e a Economia Solidária no Brasil: Instrumentos para um Novo Padrão de Desenvolvimento? Revista Orbis Latina, 1, 1.

Webb, J. W., Tihanyi, L., Ireland, R. D., \& Sirmon, D. G. (2009). You say illegal, I say legitimate: Entrepreneurship in the informal economy. Academy of Management Review, 34(3), 492-510.

World Bank. (2002). World development report: Building institutions for market. New York, NY: World and Oxford University Press.

World Bank. (2007). Finance for all?: Policies and pitfalls in expanding access. World Bank.

Yunus, M. (2007). Um mundo sem pobreza: A empresa social e o futuro do capitalismo. São Paulo: Ática.

Yunus, M. (2010). Criando um negócio social: Como iniciativas economicamente viáveis podem solucionar os grandes problemas da sociedade. Rio de Janeiro, Brazil: Ed. Elsevier. 


\section{AUTHORS}

\section{Kátia Regina Calixto Brasil}

Master in Business Administration from the University of Fortaleza -Unifor

E-mail: katiabrasil.adm@hotmail.com

ORCID: https://orcid.org/0000-0002-0446-7607

\section{Fábio Freitas Schilling Marquesan}

Doctor of Business Administration from the Federal University of Rio Grande do Sul

E-mail: marquesan@unifor.br

ORCID: https://orcid.org/0000-0002-2456-4914

\section{Rafael Fernandes de Mesquita}

Doctor of Business Administration from Universidade Potiguar - UnP

E-mail: rafael.fernandes@ifpi.edu.br

ORCID: http://orcid.org/0000-0002-4953-4885

\section{Contribution of authors}

\begin{tabular}{|c|c|c|c|c|}
\hline Contribution & [Author 1] & [Author 2] & [Author 3] & [Author 4] \\
\hline 1. Definition of research problem & $\sqrt{ }$ & $\mathrm{V}$ & & \\
\hline $\begin{array}{l}\text { 2. Development of hypotheses or research questions } \\
\text { (empirical studies) }\end{array}$ & $\sqrt{ }$ & $\sqrt{ }$ & $\sqrt{ }$ & \\
\hline $\begin{array}{l}\text { 3. Development of theoretical propositions (theoret- } \\
\text { ical work) }\end{array}$ & $\sqrt{ }$ & & & \\
\hline 4. Theoretical foundation / Literature review & $\sqrt{ }$ & $\mathrm{V}$ & $\sqrt{ }$ & \\
\hline 5. Definition of methodological procedures & $\sqrt{ }$ & $\sqrt{ }$ & & \\
\hline 6. Data collection & $\sqrt{ }$ & & & \\
\hline \multicolumn{5}{|l|}{ 7. Statistical analysis } \\
\hline 8. Analysis and interpretation of data & $\sqrt{ }$ & $\sqrt{ }$ & $\mathrm{V}$ & \\
\hline 9. Critical revision of the manuscript & $\mathrm{V}$ & $\sqrt{ }$ & $\mathrm{V}$ & \\
\hline 10. Manuscript writing & $\mathrm{V}$ & $\mathrm{V}$ & & \\
\hline 11. Other (please specify) & & & & \\
\hline
\end{tabular}

\section{Conflict of Interest}

The authors have stated that there is no conflict of interest.

\section{Copyrights}

ReA/UFSM owns the copyright to this content.

Plagiarism Check

The ReA/UFSM maintains the practice of submitting all documents approved for publication to the plagiarism check, using specific tools, e.g.: CopySpider. 